\title{
Effect of High-Intensity Interval Training and Lactobacillus Rhamnosus Probiotic Consumption on TLR4 and MYD88 Expression in Gut Tissue in Animal Model of Non-Alcoholic Fatty Liver
}

\author{
Masoumeh Mazinani ${ }^{1}$, Saeedeh Shadmehri $^{2}$, Hossein Shirvani ${ }^{3}$
}

1. M.Sc, Department of Physical Education and Sport Science Yadegar-e-Imam Khomeini (RAH) Shahre-rey Branch, Islamic Azad University, Tehran, Iran. ORCID ID: 0000-0001-5764-9562

2. Assistant Professor, Department of Physical Education and Sport Science Yadegar-e-Imam Khomeini (RAH) Shahre-rey Branch, Islamic Azad University, Tehran, Iran., (Corresponding Author), Tel: +98-21-55229351, Email: saeedehsh61@gmail.com. ORCID ID: 0000-0002-5000-4427

3. Associate Professor, Exercise Physiology Research Center, Life Style Institute, Baqiyatallah University of Medical Sciences, Tehran, Iran .ORCID ID: 0000-0002-0696-958X

\begin{abstract}
Background and Aim: The liver is exposed to large amounts of toll-like receptor ligands due to increased bacterial growth and increased intestinal permeability in the patients with fatty liver disease. The aim of this study was to investigate the effect of high-intensity interval training and Lactobacillus Rhamnosus probiotic consumption on TLR4 and MYD88 expression in gut tissue in animal model of non-alcoholic fatty liver.

Materials and Methods: In this experimental study, 40 rats (weighing 200-250 gr) were selected and randomly divided into 5 groups including healthy control, fatty liver, fatty liver + HIIT, fatty liver + probiotic and fatty liver + HIIT + probiotic groups. In order to induce fatty liver, oral tetracycline $140 \mathrm{mg} / \mathrm{kg} /$ day in $2 \mathrm{ml}$ of water in form of a solution was given to the rats by gavage for 7 days. HIIT exercise program performed on treadmill five sessions per week for 5 weeks. Data were analyzed by one-way ANOVA and Tukey post hoc tests.

$\mathrm{P}<0.05$ was considered significant.

Results: The results showed that TLR4 gene expression was significantly lower in HIIT, probiotic and also HIIT + probiotic groups than in the fatty liver group $(\mathrm{P}=0.001)$. Also, the expression of the MYD88 gene in intestinal tissue was significantly lower in HIIT, probiotic and HIIT+ probiotic groups than that in the fatty liver group $(\mathrm{P}=0.001)$.

Conclusion: Expression of TLR4 and MYD88 genes in adipose tissue induced by fatty liver, can be reduced by HIIT and probiotic intake. Therefore, these interventions can be considered as a non-pharmacological strategy in the treatment of fatty liver.
\end{abstract}

Keywords: Exercise, Non-alcoholic fatty liver, Inflammation, Probiotic

Received: Oct 18, 2020

Accepted: Jan 11, 2021

How to cite the article: Masoumeh Mazinani, Saeedeh Shadmehri, Hossein Shirvani. Effect of highintensity interval training and Lactobacillus rhamnosus probiotic consumption on TLR4 and MYD88 expression in gut tissue in animal model of non-alcoholic fatty liver. SJKU. 2021;25(3):13-24.

Copyright (C) 2018 the Author (s). Published by Kurdistan University of Medical Sciences. This is an open access article distributed under the terms of the Creative Commons Attribution-Non-Commercial License 4.0 (CCBYNC), where it is permissible to download, share, remix, transform, and buildup the work provided it is properly cited. The work cannot be used commercially without permission from the journal 


\section{تاثيرتمرينات تناوبى شديد و مصرف يروبيوتيك لاكتوباسيلوس رامنسوس بر بيان ثن هاى TLR4 و MYD88 بافت روده در مدل حيوانى كبد جرب غير الكلى}

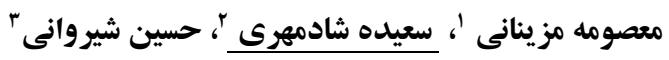

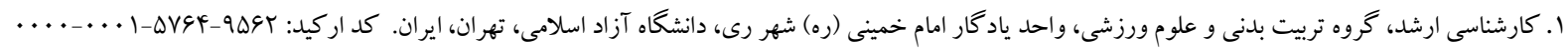

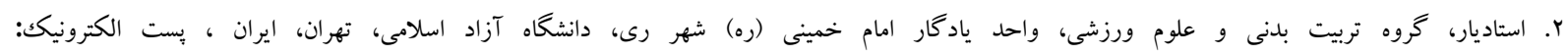

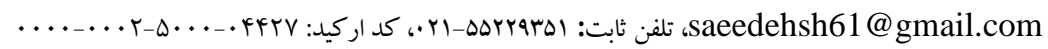

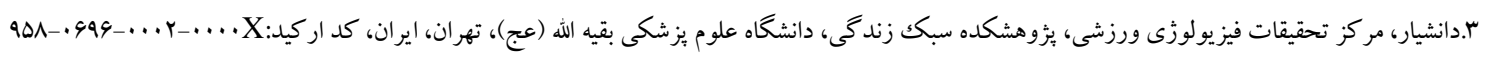

جكيده

زمينه و هدف: كبد به علت افزايش رشد باكترىها و افزايش نفوذيذيرى روده در بيمارى كبد جرب در معرض افزايش ميزان

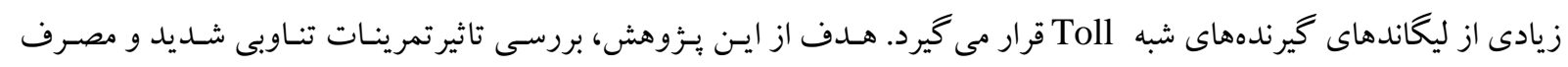

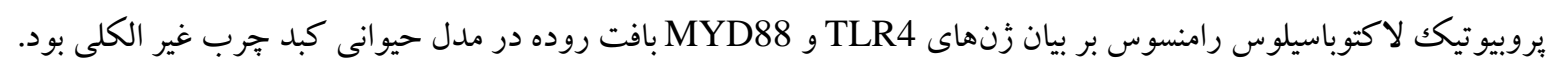

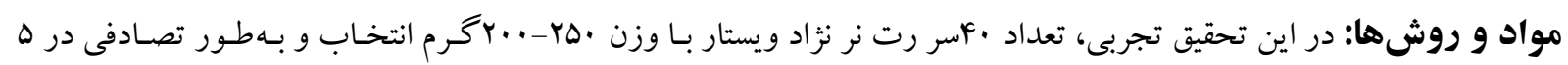

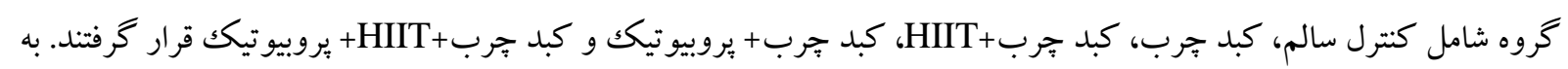

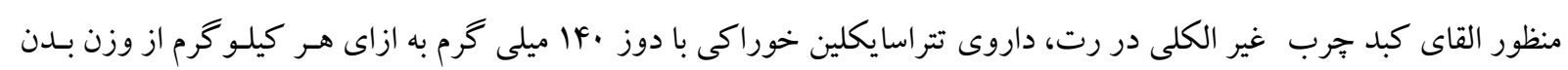

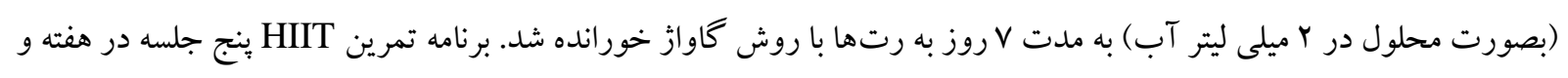

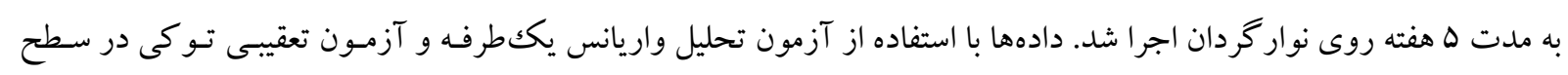
معنى دارى P<0.05 تجزيه و تحليل شد.

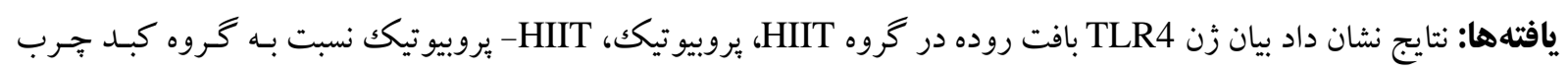

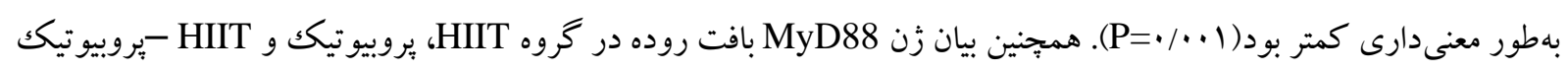

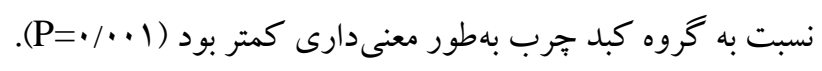

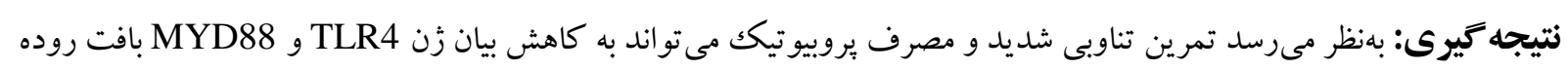

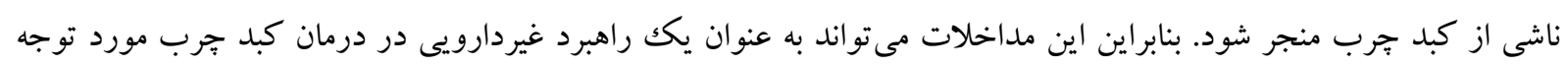

كلمات كليدى: تمرين، كبد جرب غير الكلى، التهاب، يروبيوتيكك

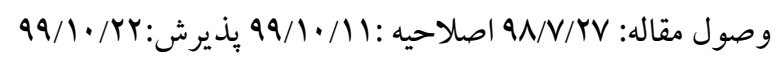


MyD88 را القا كند (r).MyD88 اولين يروتئين ضرورى در القاء ييام آبشارى TLR است و در بافت ميلوئيدى يافت مى شود. MyD نشان دهنده فعاليت تمايز ميلوئيدى و M تعداد زن هاى القا كننده بيان بروتئين MyD88 است (سا). فعال سازى IL-12p70 ميب توشود كه به طور قابل توجهى باسخ هاى ايمنى سلولى و ايمنى هومورال

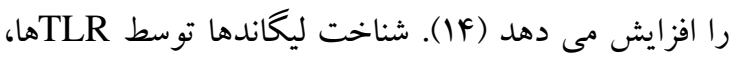

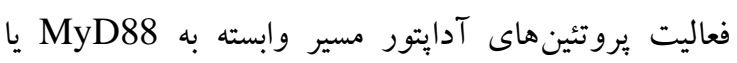

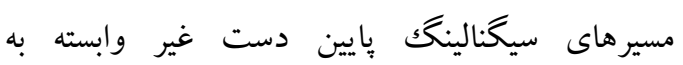

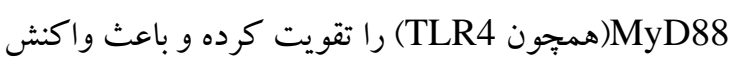

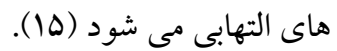
فعاليت ورزشى از طريق اثرات ضد التهابى خود، نتايج

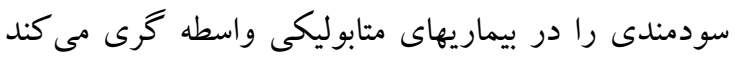
(19). جنبههاى مختلفى از فعاليت ورزشى كو تاه مدت و بلند مدت وجود دارد كه نشان مى دهد تاثير اصلى ضد التهاب ورزش ممكن است به دليل تاثيرات روى فعال سازى مسير

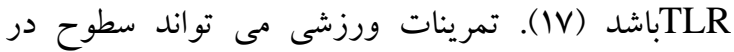
گردش ليخاندهاى TLR (كه در بيمارى هاى متابوليك افزايش ييدا مى كند) را كاهش دهد (1) (1). فعاليت ورزشى، هائ همجِنين مى تو اند بيان و فعال سازى TLR4 را در بافت هاى مختلف و انواع سلول ها كاهش دهد (19). از طرفى، برخى از گونهاى خاص يروبيوتيككها با اثر بر تركيب فلور ميكروبى روده و بهبود عملكرد آن، مانع از انتقال اندوتو كسينهاى باكتريايى به جريان خون شده و با

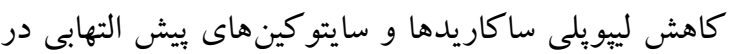
گردش خون، موجب كاهش التهاب مى گردند (·r). اثرات درمانى گزارش شده از اين ميكروار كانيسمها شامل ايجاد

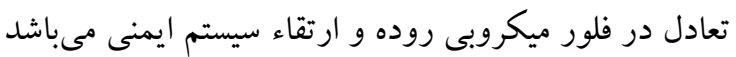

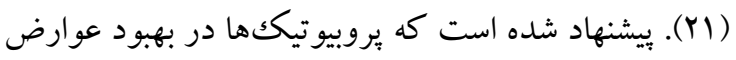
مثابوليك NAFLD موثر مىباشند (Y) (Y). بروبيوتيككها

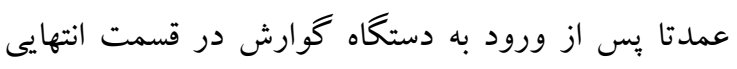
روده باريك و كلون مستقر مىشود (r) (Y). اين باكترىها

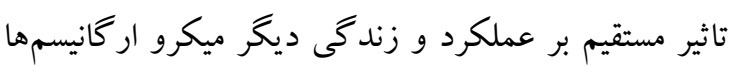

\section{مقدمه}

بيمارى كبد جرب غير الكلى Nonalcoholic NAFLD متداول ترين بيمارى مزمن كبدى (fatty liver disease, در دنيا است كه به عنوان تجمع جربىها به ويزه ترى كليسيريدها در كبد تعريف مىشود (1). كبد جرب غير الكلى طيف وسيعى از بيمارىها از استئاتوز (Steatosis) تا استئاتو هياتيت (Steatohepatitis) غير الكلى، سيروز (Cirrhosis) شامل مىشود (Y). بى تحر كى و عادت غذايى نادرست

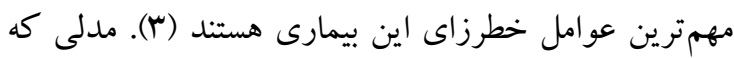

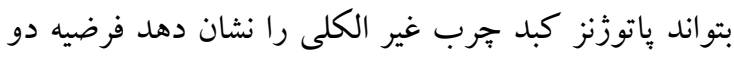
ضربهاى است كه اين بيمارى بر اثر بروز ضربهى اول همانند ابتلا به مقاومت انسولينى، جاقى و ديس ليييدمى ايجاد مى شود و بر اثر ضربههاى دوم همجيون استرس اكسيداتيو، سايتو كينهاى بيش التهابى و تو كسين هاى باكتريايى رودهاى، سلولهاى كبدى را به سمت بروز التهاب، فيبروز و

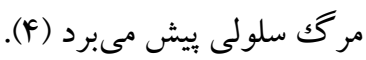
مطالعات نشان مى دهد كه كبد به علت افزايش رشد باكتريها و افزايش نفوذ يذيرى روده در بيمارى كبد جرب درمعرض افزايش ميزان زيادى از ليكاندهاى گيرندههاى شبه (Like- Toll receptor, TLR) Toll كرفته است (9) (ه). TLRs يك گروه از يروتئين هاى گيرنده متصل به غشاء هستند كه در باسخ هاى ايمنى ذاتى مشار كت دارند

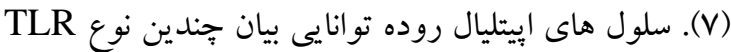
از جمله TLR4 را دارند (^). اين سلول ها به عنوان اولين سد دفاعى سيستم ايمنى مخاطى بايد بتواند بين اركانيسم

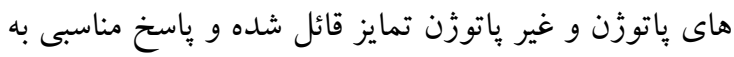
اين باكترى ها بدهد تا با ايجاد هموستازى در لومن روده از ياسخ هاى التهابى جلو گيرى كند (9). نقش كيرندههاى

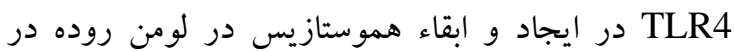
مطالعات مختلف نشان داده شده است (rا-..1). در ميان گيرنده هاى شبه تول، TLR4 به دليل هدايت سيخنالى

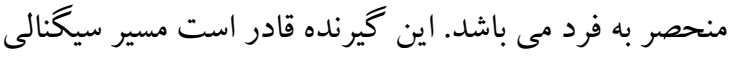


بقيه اله (عج) با كد IR.BMSU.REC.1396.716 تاييد و

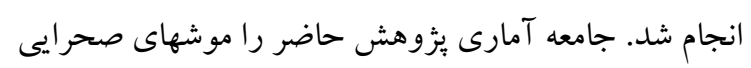

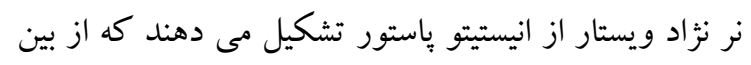

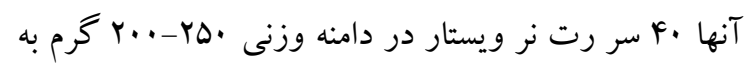

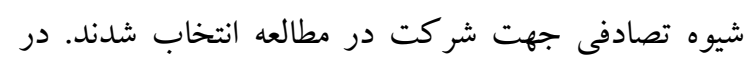

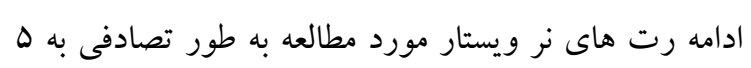

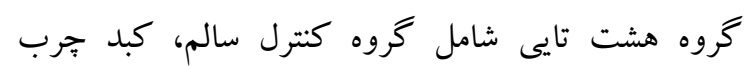

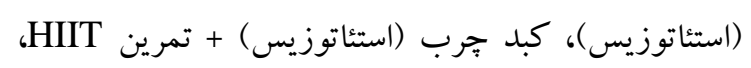

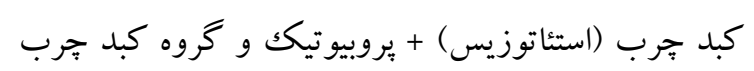

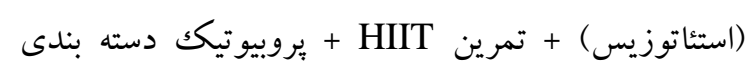

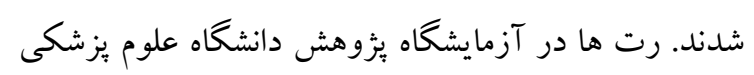

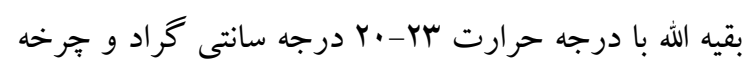

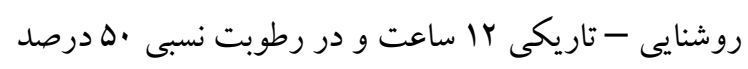
با آب و غذاى استاندارد نخهدارى شدند.

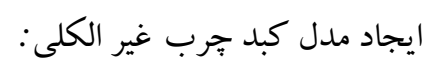

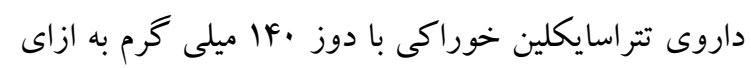
هر كيلو گرم از وزن بدن ( بصورت محلول در ب ميلى ليتر

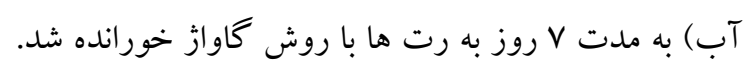

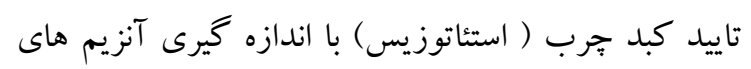

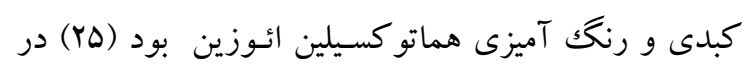

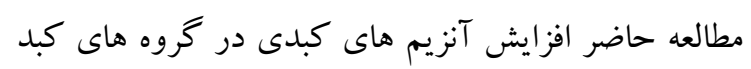
جرب مشاهده شد. بررسى در يكك بازه زمانى مناسب، تشابهات عوارض در حيوانات با انسان ها و همجِنين امكان كنترل شرايط آزمايش از مزيت هاى استفاده از اين مدل

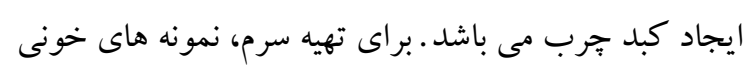

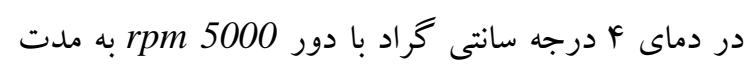
. 1 دقيقه سانتريفوز شدند. سنجش دآ آنزيم هاى كبدى شامل:AST و ALT به وسيله كيت هاى تشخيصى شركت

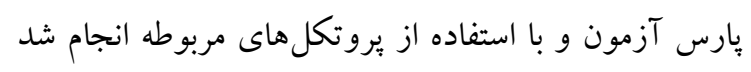

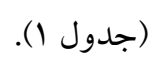

در روده داشته وعمدتا سبب تقويت باكترىهاى مفيد در

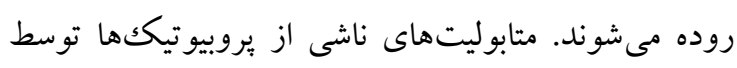

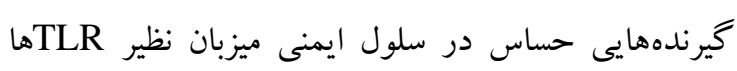
شناسايى شده و آبشارى در سلول، جهت تنظيم عملكرد

$$
\text { ايمنى به راه مىاندازند(N). }
$$

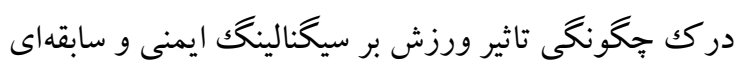
كه ايجاد مى كند براى بز شكان بالينى مفيد مى باشد. اخيرا

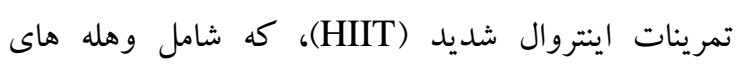

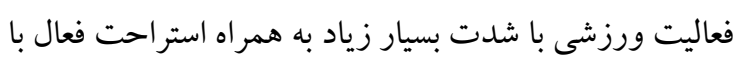
شدت بايين مى باشد، مورد توجه محققين قرار گرفته است.

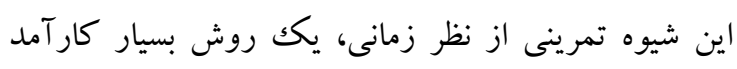

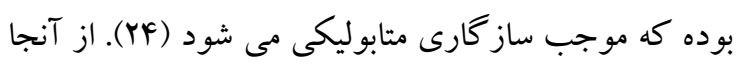

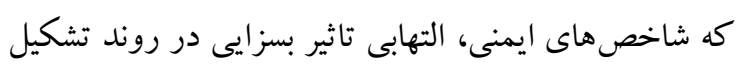

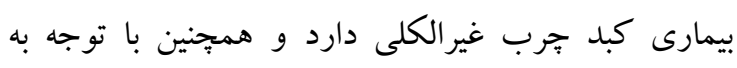

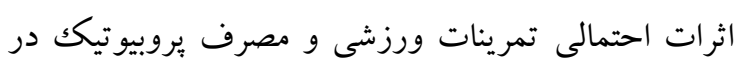

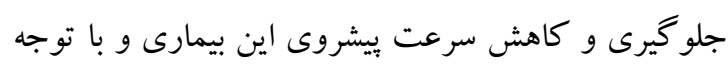

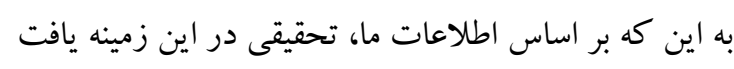

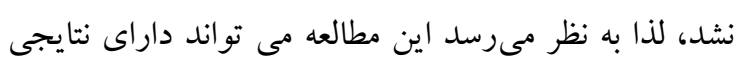

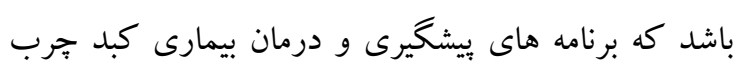
غير الكلى را به كونه اى موثر و كارامد تحت تاثي ماثير قرار دهد. يافتن مكمل هاى غذايى كه به بدن و از جمله بافت روده در

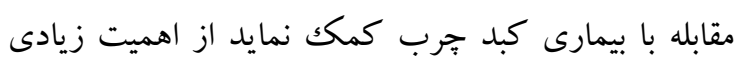

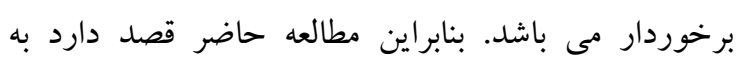

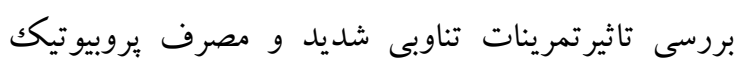

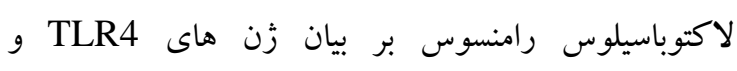

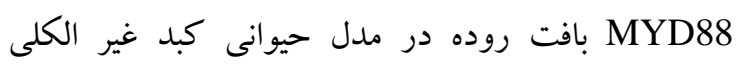

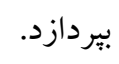

\section{مواد و روشها}

يُزوهش حاضر از نوع بنيادى و روش آن آن تجربى مى باشد.

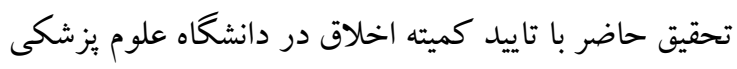


جدول ا. سطوح سرمى آنزيم هاى كبدى در كروه هاى مختلف. در هر كروه مقادير ميانكين \pm انحراف معيار فعاليت آنزيمى از

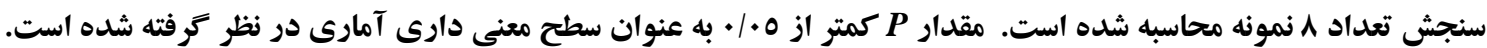
يبروبيوتيك

$\mid F r / 19 \pm r / 10$

$\mid r r / I V \pm I r / 9$

$|r| 1 / r \Delta \pm 1 \cdot / r \mid *$

$\begin{array}{cr}\| \Gamma /|r \pm F \Delta / F| & \begin{array}{c}\mathrm{AST} \\ (\mathrm{U} / \mathrm{ml})\end{array} \\ \wedge V / ৭ \pm \Delta / / F \Delta & \mathrm{ALT} \\ & (\mathrm{U} / \mathrm{ml})\end{array}$

\begin{tabular}{|c|c|c|c|c|c|}
\hline & & & & & $(\mathrm{U} / \mathrm{ml})$ \\
\hline$Q Y / \Lambda \pm \Lambda I / V \Delta$ & $9 \Delta / 1 f \pm 19 / 11$ & $a r /|r \pm \Delta \Delta / F|$ & $r Y \cdot / r V \pm \Lambda r / \Lambda \cdot * *$ & $\Lambda V / a \pm \Delta \mid / \& \Delta$ & $\begin{array}{c}\text { ALT } \\
(\mathrm{U} / \mathrm{ml})\end{array}$ \\
\hline
\end{tabular}

$$
\text { بروتكل تمرين تناوبى شديد: }
$$

در ابتدا رت ها به مدت يكك هفته ب تا ها جلسه در هفته به تصن

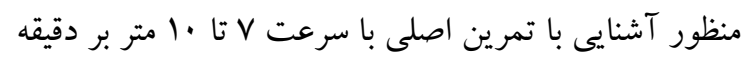

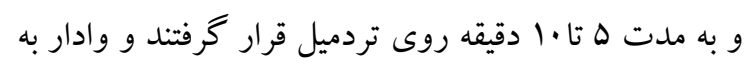

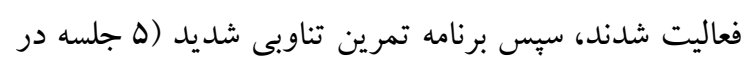

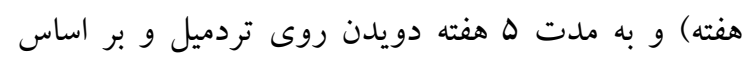

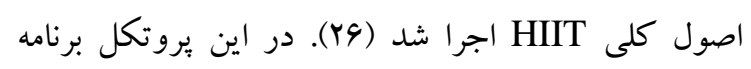

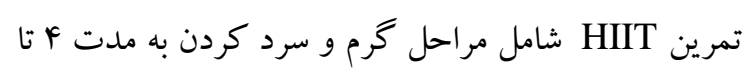

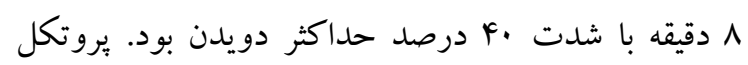
اجراى وهله هاى تمرينى در جدول ب آمده است.

كشت باكترى و نحوه مصرف بروبيو تيك: لاكتوباسيلوس رامنسوس PTCC1637) GG) بهصورت بهون

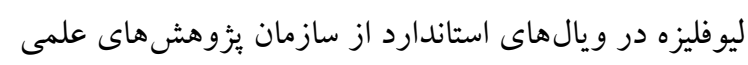
و صنعتى اير ان (تهران، ايران) خريدارى شد. باكترىها در دران

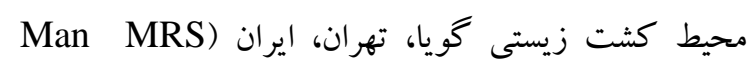
L-) HCL غنى شده با Logosa Sharp,

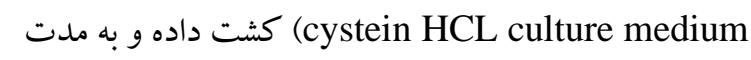

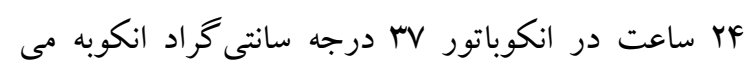
شوند. جهت بررسى تاثير مصرف بروبيوتيك ها گروه هاى مربوطه به مدت ه هفته و ها روز در هفته روزانه CFU/ml

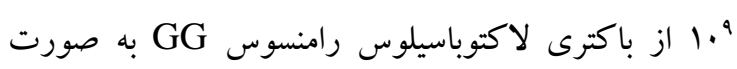

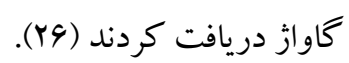
جدول r. برنامه تمرين تناوبى شديد

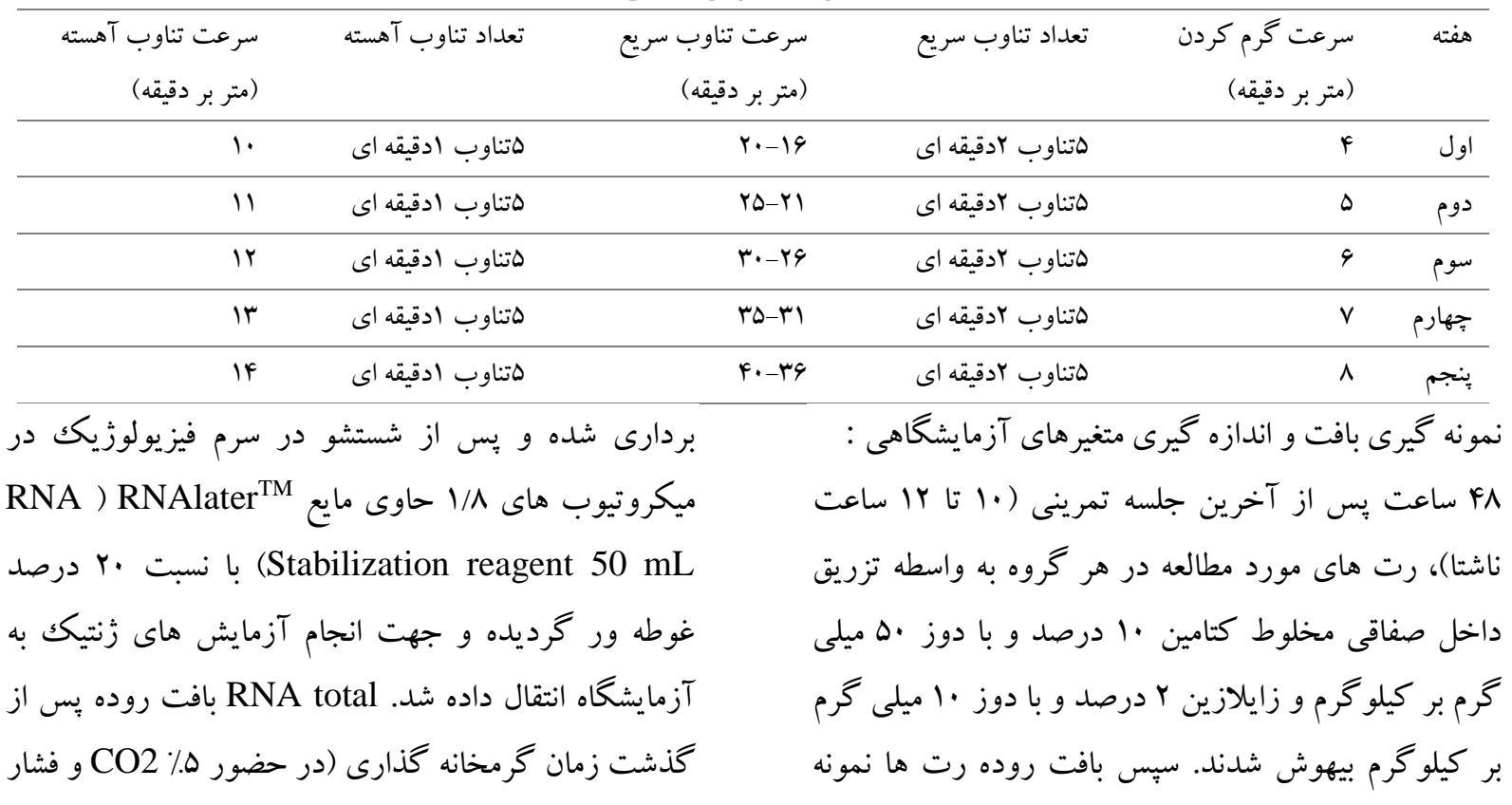


(Sequence Detection Systems. Foster City, CA طبق بروتكل شركت سازنده اندازه گيرى ABI Step One

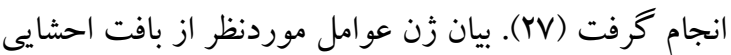

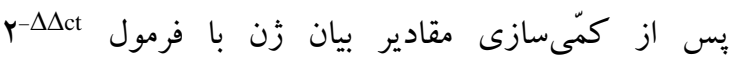

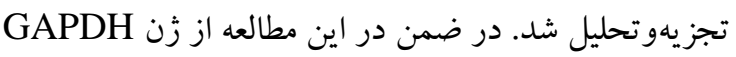

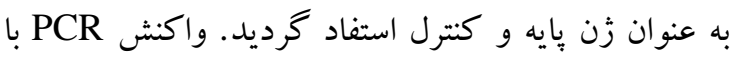
توالى برايمرهاى مورداستفاده در جدول ب ذكر شده است.

هo \% اتمسفر) براى سنجش كمى ميزان بيان زن TLR4 و RNA با استفاده از كيت ستونى استخراج MYD88 استخراج شده و پِ از آن با استفاده از كيت سنتز به CDNA (Complementary DNA, CDNA) شده و در نهايت زنهاى يادشده براى - quantitative Real آماده و با استفاده از time PCR (qRT-, PCR) g PCR master mix (Applied Biosystems) Applied Biosystems, ) در دستخاه SYBR Green جدول r. توالى ثر ايمر هاى مورد استفاده متغيرهاى مورد مطالعه

\begin{tabular}{|c|c|c|c|}
\hline نام زن & يرايمرها & 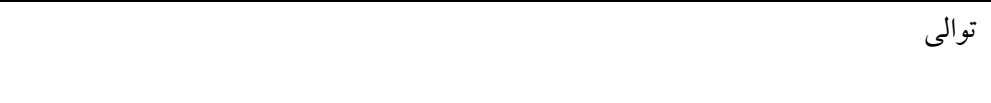 & $\begin{array}{r}\text { طول } \\
\text { amplicon }\end{array}$ \\
\hline TLR4 & $\begin{array}{l}\text { Forward } \\
\text { Reverse }\end{array}$ & TATCGGTGGTCAGTGTGCTT CTCGTTTCTCACCCAGTCCT & $104 \mathrm{bp}$ \\
\hline MYD88 & $\begin{array}{l}\text { Forward } \\
\text { Reverse }\end{array}$ & AAATTGTGTGTGTCCGACCG AGAAACAACCACCACCATGC & $123 \mathrm{bp}$ \\
\hline GAPDH & $\begin{array}{l}\text { Forward } \\
\text { Reverse }\end{array}$ & $\begin{array}{l}\text { CAAGTTCAAGGGCACAGTCA } \\
\text { CCCCATTTGATGTTAGCGGG }\end{array}$ & 104 bp \\
\hline
\end{tabular}

هاى مختلف تحقيق، تفاوت وجود دارد ( ( P= ( P). نتايج

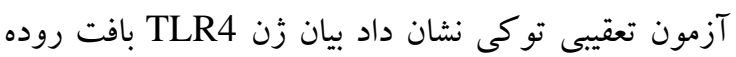

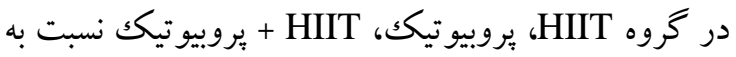

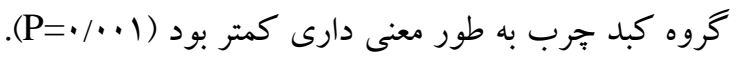

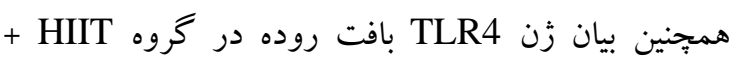

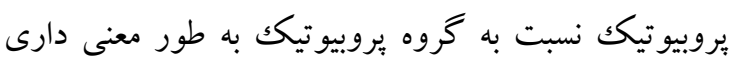

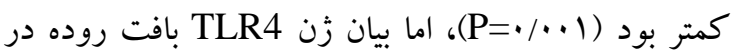
كروه HIIT نسبت به گروه HIIT + بروبيو تيكك تفاوت معنى دارى وجود نداشت (P=/AY) (نمودار ().

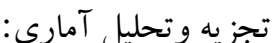
يساز اينكه نرمال بودن دادهها با آزمون شاييرو ويلك تأسيد

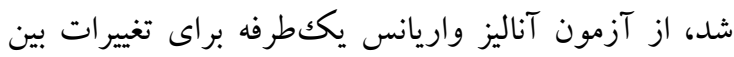
كروهى و آزمون تعقيبى توكى براى بررسى تفاوت بين

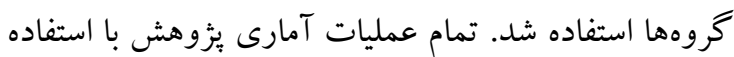
از نرم افزار SPSS نسخه سץ انجام شد و سطح معنى دارى

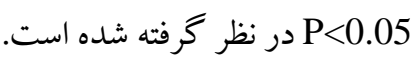

يافتهها

تجزيه و تحليل دادهها نشان داد كه بين ميانگين بيان زُن

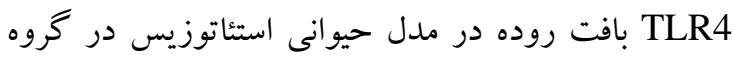




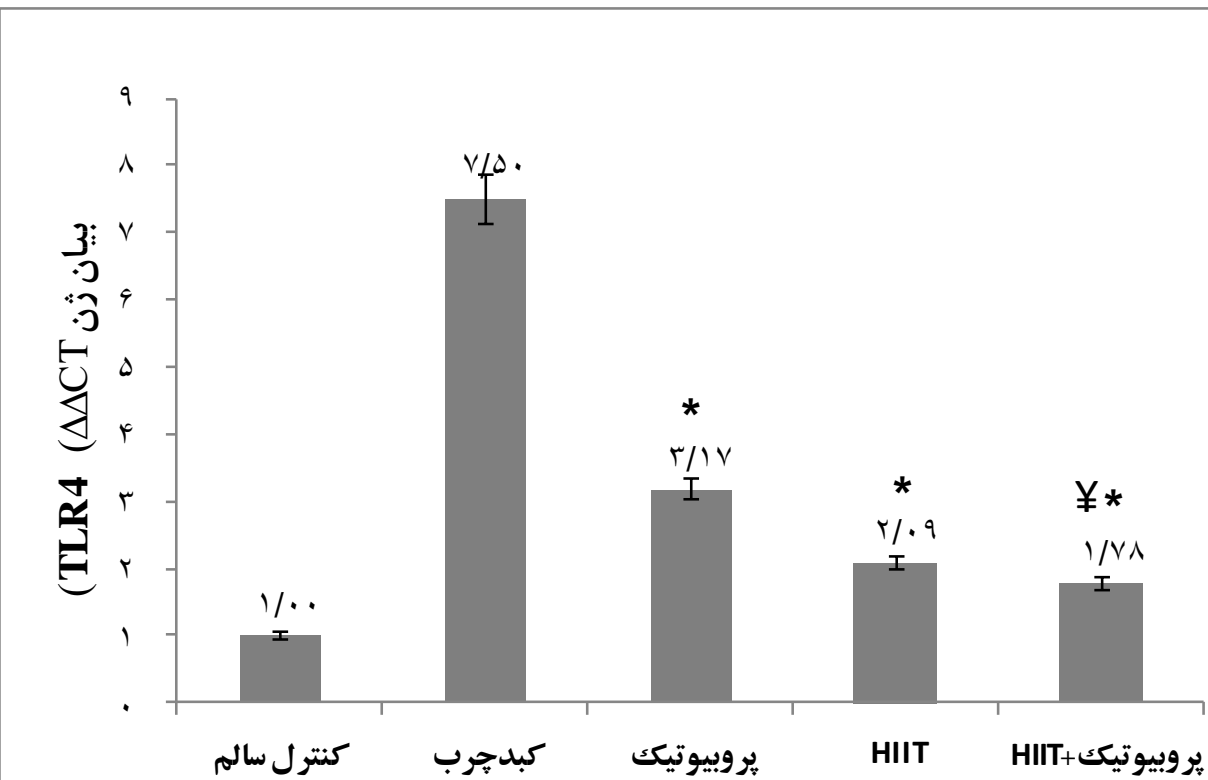

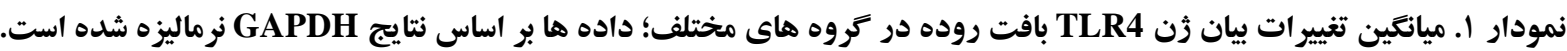

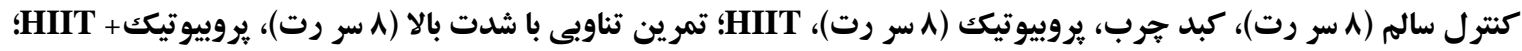

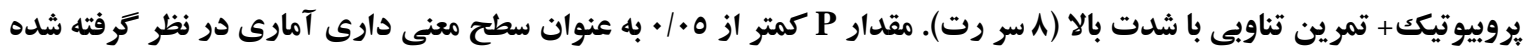

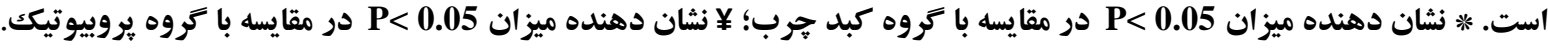

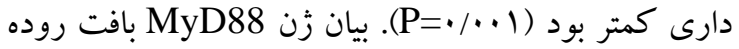

در گروه بروبيوتيك، گروه HIIT و گروه HIIT يروبيو تيكك تفاوت معنى دارى نداشت (نمودار Y).
تجزيه و تحليل داده ها نشان داد كه بين ميانكين بيان زن MYD88 بافت روده در مدل حيوانى استئاتوزيس در گروه هاى مختلف تحقيق، تفاوت وجود دارد ( ( + P=/.). بيان زن MyD88 بافت روده در گرووه HIIT، يروبيوتيكك و + HIIT 


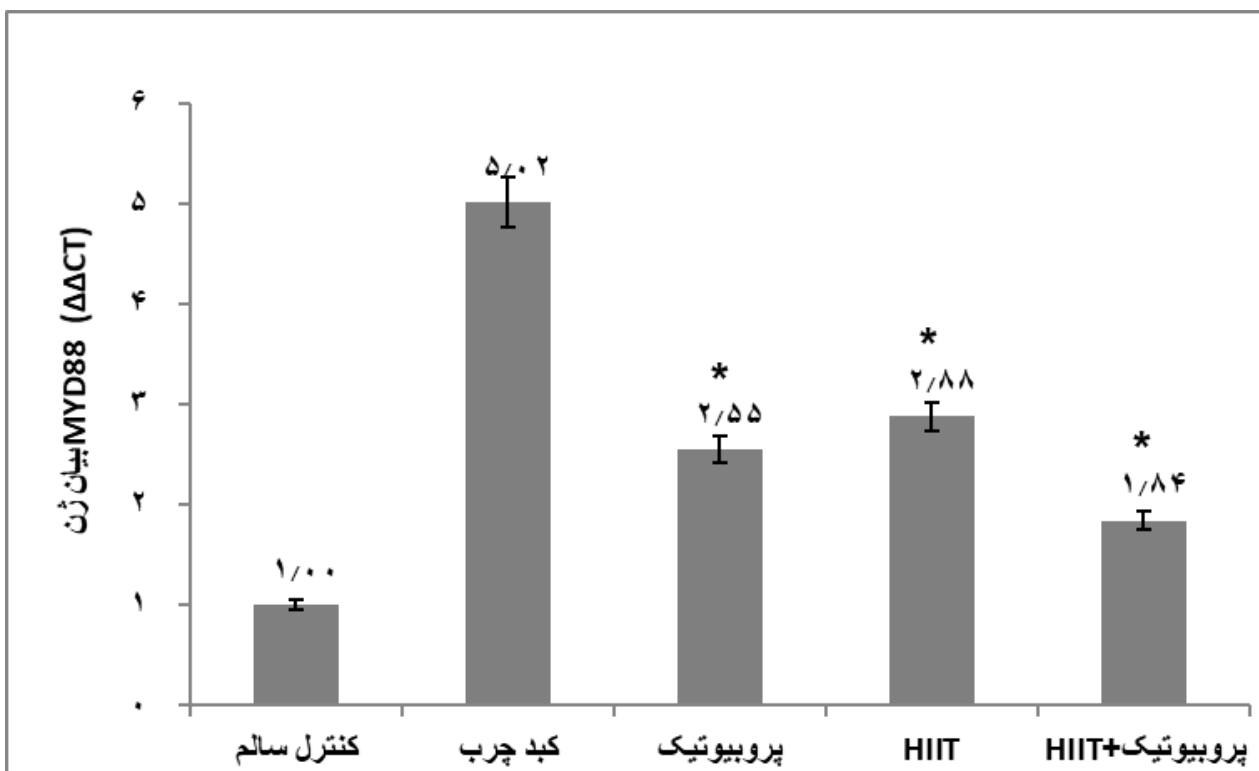

نمودار r- ميانكين بيان زن MYD88 بافت روده در كروه هاى مختلف؛ داده ها بر اساس نتايج GAPDH نرماليزه شده است.

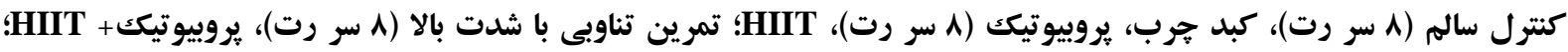

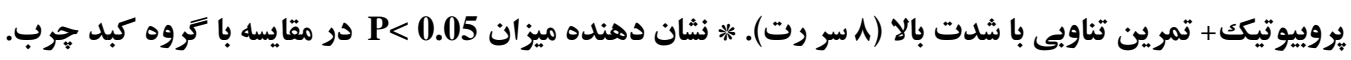

شو كى گرمايى و كلو كو كورتيكوئيد مى تواند منجر به مهار

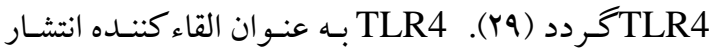
سايتو كين ها شناخته شده است (ها ). به نظر مىرسد كه بيان IL-10 توسط سـايتو كينهـاى ضـالتهابى IL-4TL4 تعديل مىشود (19) (19) بنابر اين ممكن است كـه افزايش بيـان سايتو كينهاى ضدالتهابى ناشى از تمرين عامل مهار TLR4

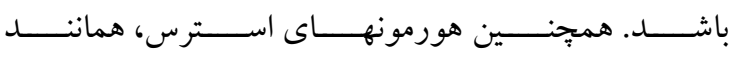
كلوكو كورتيكوئيدها نقش مهمى در تعديل و تنظيم سيستم

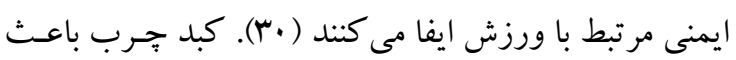
كاهش سطوح HSP هـا مسى گـردد (1) (1). كـاهش سطوح - ها باعث افزايش فعال شدن سايتو كين هاى التهابى مى HSP شود ( اس). فعاليتهاى ورزشى باعـث افزايش سطح HSP و منجر به مهار فعالسازى P38MAPK مىشود (اسM). بنابراين به نظر مىرسد كه فعاليتهاى ورزشى از طريق افزايش سطوح برو تئينهاى شـوك كرمـايى باعـث مهـار كيرنسـه TLR4 و كـاهش سـوح سـايتو كينهـاى التهـابى شـود. سـيخنالينخ
يافته هاى تحقيق حاضر نشـان مسى دهـد كـه كبــ جـرب بــا افـزايش بيـان زن TLR4 و MYD88 همــاه بــود. تمــرين تنـاوبى شـديد و مصـرف بروبيو تيـك موجـب كـاهش بيـان

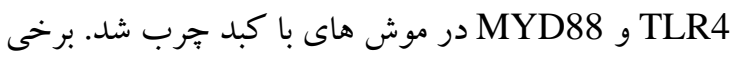
مطالعـات اخيـر نشـان داده انـد كـه تمرينـات ورزشسى بيـان كيرنسـدهـاى شـبه تـول و MYD88 را كـاهش مسى دهنــ

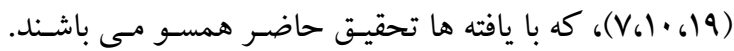
فعاليـتهــاى ورزشـى شــديد باعـث تغييــرات اساسـى در زير گـروههــاى منوسـيت خـون شـده و بيـان سـطح سـلولى كيرندهاى آنها مثل TLR هـا را تغييـر مسىهنـــ فعاليـت ورزشى شديد ترجيحاً باعث فراخـوانى منوسـيتهـاى يـيش التهابى شده و نسبت منوسيت هاى ييش التهابى به منوسيتهاى

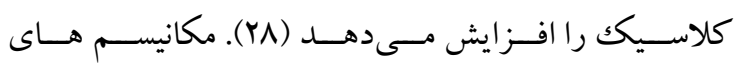
فيزيولوزيكى دقيق اين تغييرات هنوز شناخته نشده اند. با اين حال، بـه نظـر مسىرســ كـه فعاليـتهـاى ورزشـى از طريـق

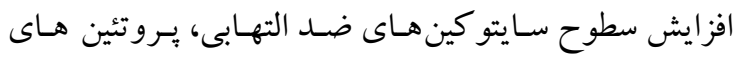


تخمير آنها و تر كيبات ديواره سـلولى و يِيتـدو كليكان و هـر بخشى از باكترى حتى DNA نسبت مىدهنـد (A). مكانيسم اثر بيوتيكك ها از سه طريـق ذكر شـده اسـت كـه شـامل: اتاثيرات آنتى ميكروبى مستقيم Y-تقويت تماميت سد دفـاعى مخاطى بـ- تغير ات مطلوب در سيستم ايمنسى بــن مسى باشـد (Y.). از سوى ديكر مشخص شده كه فلسور ميكروبسى روده، تحت تاثير رزيـم غـذايى اسـت. نشـان داده شـده اسـت كـه تجويز يروبيوتيكها از طريق دستـارى در فلسور ميكروبسى روده التهاب درجه يايين روده ایى را كـاهش داده و تماميـت

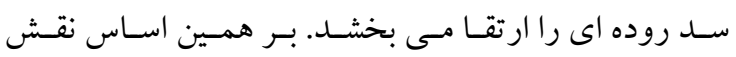

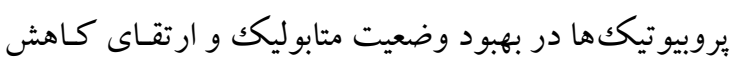

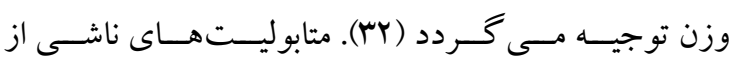
يروبيوتيككها توسط گيرندهـايى حسـاس در سـلول ايمنسى ميزبان نظير TLR هـا شناسـايى شـده و آبشـارى در سـلول، جهت تنظيم عملكرد ايمنى بـه راه مسى اندازنـد. بنـابراين هـم سـلولهاى إيتليـال در روده و هـم سـلولهاى سيستم ايمنسى اطر اف دستخاه كوارش عوامل هدف ايـن سـلولهـا هسـتند

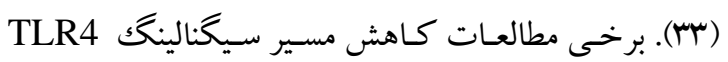
و MyD88 را نشان داده اند كه با يافته هاى تحقيـق حاضـر همخوان مى باشند (ها-سM). در مطالعهاى كه توسط فينامور

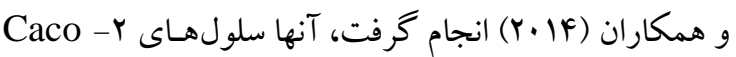
را با لاكتوباسيلوس رامنوس تحت درمان قرار دادنسد و تـاثير آنرا روى مسير سيخنالينگك TLR4 مورد بررسى قرار دادند.

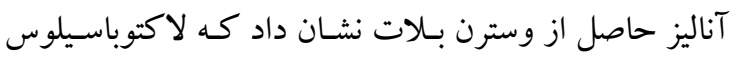
رامنوس فعاليت مسيرهاى مختلف سيخنالينك TLR4 رادر سـلولهـاى Caco-2 سـر كوب مسى كنـد (سM). كاسـيلو و و

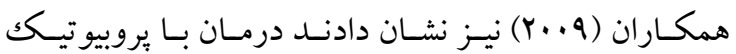

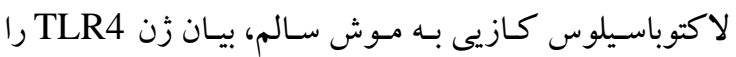
كاهش مسىدهـ (YY). زن TLR4 همـانطور كـه كفتـه شـد خانو اده PRR هـا و مسسير سـيگنالينگك درگير در سيستم ايمنى ذاتى مى باشند و اين بـدين معناسـت كه بروبيو تيك كارايى سيستم ايمنى ذاتى را تقويت مى كنـد

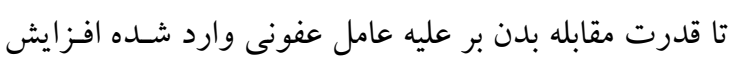

وابسته به MyD88 نيز بـراى تمـام TLR رايج است. اين امر شامل مرحله اوليه فعالسـازى KB-NF طريق مسير كيناز مربوط به R-IL-IR IRAK اسـت ( • ). سيخنالينگ غيروابسته به MyD88 از طريق TRIF صورت كرفتهه و توسط TLR3 TLR2 مسورد استفاده قرار مسى كيرد. شناخت ليكاندها توسط TLR ها، فعاليـت برو تئينهاى آدايتور مسير وابسته بـه MyD88 يـا مسـيرهاى سـيخنالينگك يايين دست غيروابسته به MyD8 و TLR4را تقويت كرده و باعـث واكــش هـاى التهـابى مسىشـود ( • (1). TLR4 بــ ليگاندهايى مانند يلى ساكاريد جرب (LPS) واكنش نشـان داده و ياسخ خود را از طريق تشكيل كميلكسى بــا ميلوئيــ افتراقى فاكتور Y) (MD-2) آغاز مى كند كه باعث فعالسازى آبشارهاى وابسته و غير وابسته به MyD88 مى گردد (س (I). با اين حال يافته هاى تحقيق حاضر با نتـايج برخهى مطالعـات

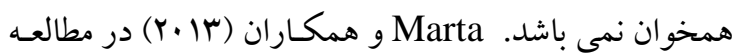
اي بـه بررسـى اثـرات تمـرين تنـاوبى شـديد بـر سـطح بيـان در افراد با شاخص توده بدنى بالا يرداختند و بـه ايسن نتيجه رسيدند كه Y هفته تمرين تناوبى شـديد (سـه جلسـه در هفته) باعث افزايش معنى دار بيان TLR4در منوسـيت هـاى كلاسيك و يُش التهابى در مردان غير فعال با شاخص تـوده بدنى بالا شده است. تناقض با يافته هاى فوق ممكن است به عواملى مانند كم بودن مدت تمرين در هر جلسه و يا دورهُ تمرينى مربوط باشد. در تحقيق حاضر تمرين تناوبى شديد و مصرف بروبيوتيكك به تعديل بيان زن هاى در گير در سيستم ايمنسى ذاتى بافـت روده ناشى از كبد جرب منجر شد. تعديل پاسخ ايمنى مسى -

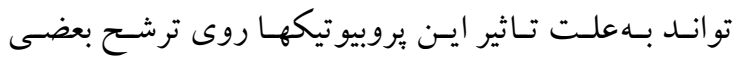
سايتو كين ها و بيان زنهاى دخيل در ايمنى ذاتى باشـــ. نـوع اثـر يروبيو تيـكك، بـه توليـــ متابوليـت بيوشـيميايى آنهـا يـا مولكولهاى موجود بر سطح اين ميكروار كانيسمها يا اجززاى

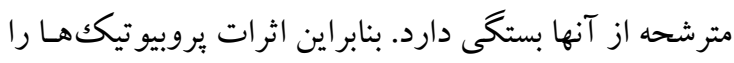

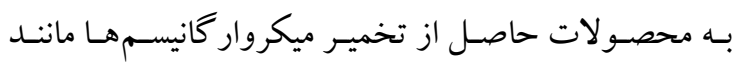
ييتيدها و يليسا كاريدهاى خارج سـلولى توليـد شـده در طـى 


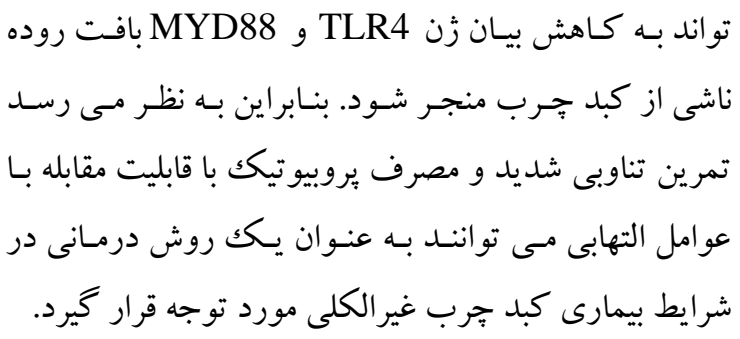

\section{تشكر و قدردانى}

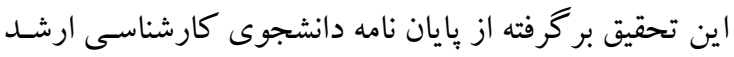

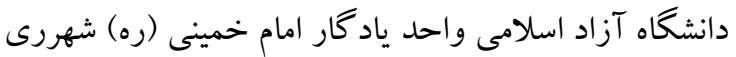

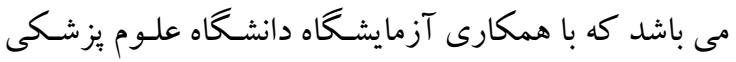

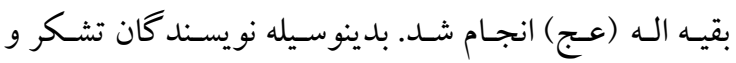
قدردانى خود را از دانشگاه آزاد اسلامى واحد ياد كَار امـام

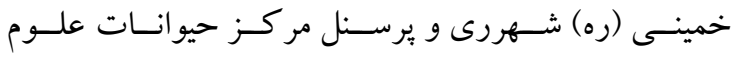
آزمايشگاهى دانشكاه علوم يزشكى بقيه اله (عج)، اعلام

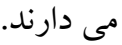

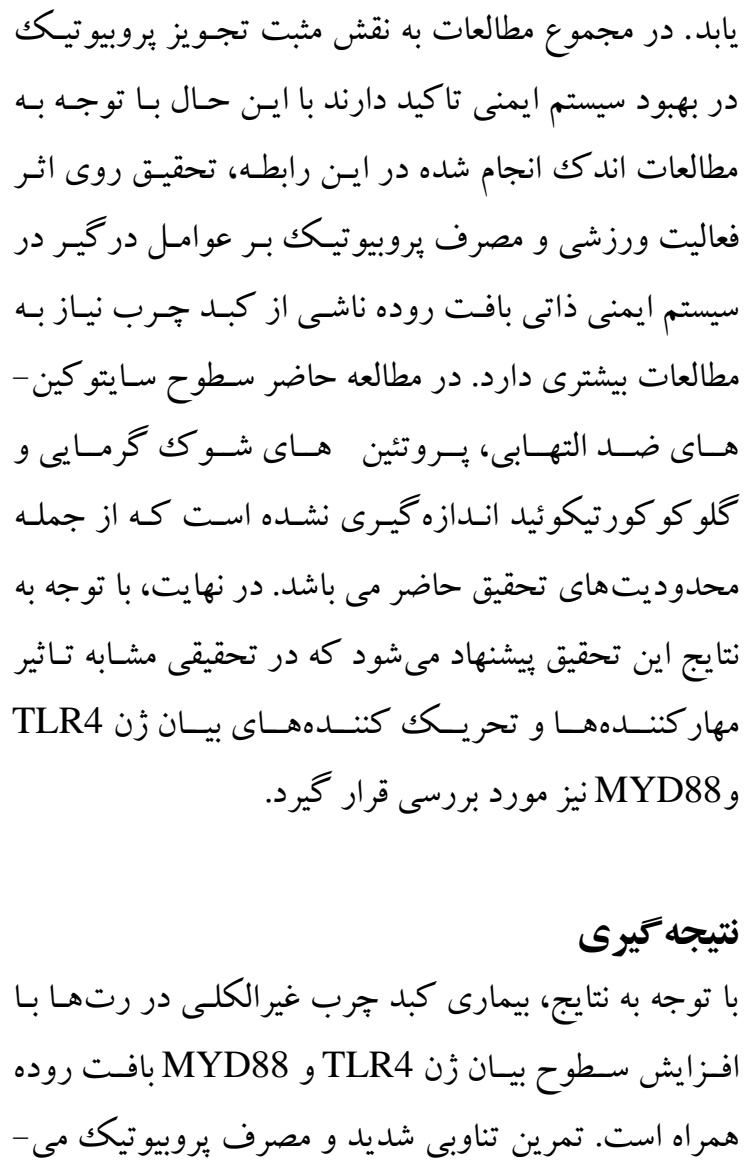

منابع

1.Ferolla SM, Ferrari TC, Lima ML, Reis TO, Tavares-Jr WC, Couto OF, et al. Dietary patterns in Brazilian patients with nonalcoholic fatty liver disease: a cross-sectional study. Clinics (Sao Paulo). 2013;68(1):11-7.

2.Martin-Dominguez V, Gonzalez-Casas R, MendozaJimenez-Ridruejo J, Garcia-Buey L, Moreno-Otero R. Pathogenesis, diagnosis and treatment of nonalcoholic fatty liver disease. Rev Esp Enferm Dig. 2013;105(7):409-20.

3.Hashimoto E, Tokushige K. Prevalence, gender, ethnic variations, and prognosis of NASH. J Gastroenterol. 2011;46(1):63-9.

4.Oddy WH, Herbison CE, Jacoby P, Ambrosini GL, O'Sullivan TA, Ayonrinde OT, et al. The Western dietary pattern is prospectively associated with nonalcoholic fatty liver disease in adolescence. Am J Gastroenterol. 2013;108(5):778-85.

5.Bonora E, Targher G. Increased risk of cardiovascular disease and chronic kidney disease in NAFLD. Nat Rev Gastroenterol Hepatol. 2012;9(7):372-81.

6.Kaser S, Ebenbichler C, Tilg H. Pharmacological and nonpharmacological treatment of nonalcoholic fatty liver disease. Int J Clin Pract. 2010;64(7):968-83.

7.Oliveira AG, Carvalho BM, Tobar N, Ropelle ER, Pauli JR, Bagarolli RA, et al. Physical exercise reduces circulating lipopolysaccharide and TLR4 activation and improves insulin signaling in tissues of DIO rats. Diabetes. 2011;60(3):784-96. 
8.Nandakumar N, Pugazhendhi S, Ramakrishna B. Effects of enteropathogenic bacteria \& lactobacilli on chemokine secretion \& Toll like receptor gene expression in two human colonic epithelial cell lines. Indian J Med Res. 2009;130(2):170-8.

9.Child M, Leggate M, Gleeson M. Effects of two weeks of high-intensity interval training (HIIT) on monocyte TLR2 and TLR4 expression in high BMI sedentary men. IJES. 2013;6(1):81-90.

10.Ma Y, He M, Qiang L. Exercise therapy downregulates the overexpression of TLR4, TLR2, MyD88 and NF- $\kappa$ B after cerebral ischemia in rats. Int J Mol Sci. 2013;14(2):3718-33.

11.Zarember KA, Godowski PJ. Tissue expression of human Toll-like receptors and differential regulation of Toll-like receptor mRNAs in leukocytes in response to microbes, their products, and cytokines. J Immunol. 2002;168:554-61.

12.Alexopoulou L, Holt AC, Medzhitov R, Flavell RA. Recognition of double-stranded RNA and activation of NF-kappaB by Toll-like receptor 3. Nature. 2001;413:732-8.

13.Larsson E, Tremaroli V, Lee YS, Koren O, Nookaew I, Fricker A, et al. Analysis of gut microbial regulation of host gene expression along the length of the gut and regulation of gut microbial ecology through MyD88. Gut. 2012;61(8):1124-1131.

14.Ve T, Williams SJ, Kobe B. Structure and function of Toll / interleukin-1 receptor/resistance protein (TIR) domains. Apoptosis. 2015;20:250-61.

15.Kumar H, Kawai T, Akira S. Toll-like receptors and innate immunity. Biochem Biophys Res Commun. 2009; 388:621-5.

16.Park BS, Song DH, Kim HM, Choi BS, Lee H, Lee JO. The structural basis of lipopolysaccharide recognition by the TLR4-MD-2 complex. Nature. 2009;458:1191-5.

17.Takeda K, Kaisho T, Akira S. Toll-like receptors. Annu Rev Immunol. 2003;21:335-76.

18.Jackson DC, Lau YF, Le T, Suhrbier A, Deliyannis G, Cheers C, et al. A totally synthetic vaccine of generic structure that targets Toll-like receptor 2 on dendritic cells and promotes antibody or cytotoxic T cell responses. Proc Natl Acad Sci. 2004;101:15440-5.

19.Fernandez-Gonzalo R, De Paz JA, RodriguezMiguelez P, Cuevas MJ, Gonzalez-Gallego J. TLR4- mediated blunting of inflammatory responses to eccentric exercise in young women. Mediators Inflamm. 2014;1-11.

20.Hertz CJ, Kiertscher SM, Godowski PJ, Bouis DA, Norgard MV, Roth MD, et al. Microbial lipopeptides stimulate dendritic cell maturation via Toll-like receptor 2. J Immunol. 2001; 166:2444- 50.

21.Pischon T, Hankinson SE, Hotamisligil GS, Rifai N, Rimm EB. Leisuretime physical activity and reduced plasma levels of obesityrelated inflammatory markers. Obes Res. 2003;11(9):1055-64.

22.Ziccardi P, Nappo F, Giugliano G, Esposito K, Marfella R, Cioffi M, et al. Reduction of inflammatory cytokine concentrations and improvement of endothelial functions in obese women after weight loss over one year. Circulation. 2002;105(7):804-9.

23.Kawai T, Akira S. Signaling to NF-kappaB by Toll-like receptors. Trends Mol Med. 2007;13:460-9.

24.Batacan RB, Duncan MJ, Dalbo VJ, Tucker PS, Fenning AS. Effects of high-intensity interval training on cardiometabolic health: a systematic review and meta-analysis of intervention studies. Br J Sports Med. 2017;51:494-503.

25.Shabana MB, Ibrahim HM, Khadre SE, Elemam MG. Influence of rifampicin and tetracycline administration on some biochemical and histological parameters in albino rats. JOBAZ. 2012;65(5):299-308. 
26.Kalaki-Jouybari F, Shanaki M, Delfan M, Gorgani-Firouzjae S, Khakdan S. High-intensity interval training (HIIT) alleviated NAFLD feature via miR-122 induction in liver of high-fat high-fructose diet induced diabetic rats. Arch Physiol Biochem. 2018;3:1-8.

27.Shafie A, Moradi F, Izadpanah E, Mokarizadeh A, Moloudi MR, Nikzaban M, et al. Neuroprotection of donepezil against morphine-induced apoptosis is mediated through Tolllike receptors. Eur J Pharmacol. 2015;764:292-297.

28.Carpenter KC, Strohacker K, Breslin WL, Lowder TW, Agha NH, McFarlin BK. Effects of exercise on weight loss and monocytes in obese mice. Comp Med. 2012;62(1):21-6.

29.Wu XD, Zeng K, Liu WL, Gao YG, Gong CS, Zhang CX, et al. Effect of aerobic exercise on miRNA-TLR4 signaling in atherosclerosis. Int J Sports Med. 2014;35(4):344-50.

30.Rosa JC, Lira FS, Eguchi R, Pimentel GD, Venancio DP, Cunha CA, et al. Exhaustive exercise increases inflammatory response via Toll like receptor-4 and NF-kappaBp65 pathway in rat adipose tissue. J Cell Physiol. 2011;226(6):1604-7.

31.Rodriguez-Miguelez P, Fernandez-Gonzalo R, Almar M, Mejías Y, Rivas A, de Paz JA, Cuevas MJ, González-Gallego J. Role of Toll-like receptor 2 and 4 signaling pathways on the inflammatory response to resistance training in elderly subjects. Age (Dordr). 2014;36(6):9734.

32.Ganguli K, Collado MC, Rautava J, Lu L, Satokari R, von Ossowski I, et al. Lactobacillus rhamnosus GG and its SpaC pilus adhesin modulate inflammatory responsiveness and TLRrelated gene expression in the fetal human gut. Pediatr Res. 2015;77(4):528-35.

33.Finamore A, Roselli M, Imbinto A, Seeboth J, Oswald IP, Mengheri E. Lactobacillus amylovorus inhibits the TLR4 inflammatory signaling triggered by enterotoxigenic Escherichia coli via modulation of the negative regulators and involvement of TLR2 in intestinal Caco-2 cells and pig explants. PLoS One. 2014;9(4):e94891.

34.Castillo NA, Perdigón, G, de Moreno de LeBlanc, A. Oral administration of a probiotic Lactobacillus modulates cytokine production and TLR expression improving the immune response against Salmonella enterica serovar Typhimurium infection in mice. BMC Microbiol. 2011;3(11):177-186.

35.Soltan Dallal MM, Moshiri M, Mirshafiey A, Douraghi M, Rezaie F, Gholami M. Evaluation of the effect of probiotic bacteria Lactobacillus acidophilus PTCC1643 and Lactobacillus casei PTCC 1608 on the TLR2 and TLR4 expression in HT29 cells infected with Salmonella enteritidis. Tehran Univ Med J. 2019;76(11):724-730. 